\title{
Danger Zones Dead Ahead For The U.S. And China: Prospects And Challenges
}

Linnea B. McCord, Pepperdine University, USA

Terry Young, Pepperdine University, USA

Peggy J. Crawford, Pepperdine University, USA

\begin{abstract}
To be successful and remain independent, every country must create a prosperous economy, keep peace among its people, maintain political stability, and ensure the security of the people and the country from internal and external threats. Doing all four at the same time is never easy and in a time of economic volatility, change, and uncertainty juggling all four becomes more difficult. This is when countries enter the danger zone where hidden cracks and fissures in a country's organization and structure could become destabilizing.
\end{abstract}

In this paper we will compare the challenges and prospects for the United States and China as both countries enter the danger zone. The purpose of this paper is to examine how each country's unique attributes are likely to impact its ability to succeed. We will examine their political, economic and legal systems to determine the strengths and weaknesses of each. We will also assess the role of corruption in each society.

Both the United States and China have serious economic, social, political and security issues on the horizon. To solve the problems will require serious sacrifices and pain for a large portion of the populations in both countries. Which form of government will best be able to adapt quickly to the constantly changing environment? Will a serious economic slowdown topple the Communist dictatorship in China? Will gridlock and distrust in the U.S. prevent Americans from adapting fast enough to make the necessary changes in time to save its financial system and economy? Time will tell.

Keywords: China; United States; Economy; Legal System

\section{INTRODUCTION}

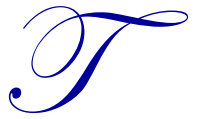

o be successful and remain independent, every country in the world must be able to do the same four things: 1) create a prosperous economy, 2) keep peace among its people, 3) maintain political stability, and 4) ensure the security of the people and the country from internal and external threats. ${ }^{1}$ Doing all four at the same time is never easy even in the best of times. In a time of economic volatility, constant change, and uncertainty - like now - juggling all four becomes much more difficult. This is when countries enter the danger zone where hidden cracks and fissures in a country's organization and structure could become destabilizing.

It is in an era of economic hardship and insecurity that countries learn the true strengths and weaknesses of their social, political, economic, cultural and legal frameworks. If economic and financial jolts are severe enough sometimes countries can morph into something truly terrible. The rise of Adolf Hitler and Nazi Germany can be traced to the failure of the Viennese bank Credit-Anstalt in May of $1931 .^{2}$ Germany's democratically-elected government lost credibility in the virulent hyperinflation of the 1920s that wreaked economic havoc on the German people. When the Austrian bank failure sparked violence in the streets, a sizeable portion of the German electorate

\footnotetext{
${ }^{1}$ Parts of this paper are based on an upcoming book by Linnea B. McCord, The Wisdom of Ants (10 Commandments of Trust): Restoring the Secret Power of Trust That Made America Great, Before It's Too Late.

${ }^{2}$ Coy, Peter. (2011). Lessons from the Credit-Anstalt Collapse. Bloomberg BusinessWeek. Retrieved from: http://www.businessweek.com/magazine/content/11_18/b4226012481756.htm
} 
turned to Adolf Hitler, believing him to be the decisive leader who could rescue them from anarchy and economic calamity. Once appointed to power by Germany's elected President, Hitler quickly hijacked Germany's fragile democracy. In a few short years, Hitler turned Germany's freely-elected government into one of the most brutal dictatorships in world history.

In this paper, we will compare the challenges and prospects for the United States and China as both countries enter the danger zone of economic volatility and uncertainty. The purpose of this paper is to examine how each country's unique attributes are likely to impact its ability to succeed in today's era of turmoil and constant change. We have chosen to compare the United States and China because the U.S. is still the largest economy in the world. China, having surpassed Japan in 2010, is now the second largest economy in the world. Each country's ability to successfully juggle all four success factors in today's changed conditions will depend on their own unique history, background, culture, and attitudes. In many respects, the U.S. and China are almost diametrically opposite. At the same time, the U.S. and China are deeply dependent on one another. China depends on the U.S. to buy its goods and the U.S. depends on China to continue buying some of its whopping national debt, which is now more than $\$ 16$ trillion and is growing rapidly at more than $\$ 1$ trillion a year.

\section{THE UNITED STATES}

\section{Background}

Since its inception almost four hundred years ago, the United States has followed a "bottom-up" selfdetermining approach to governance. Although a British colony, early American settlers made a lot of their own decisions. Britain was thousands of miles away across an ocean that took many months to cross. From the earliest days, Americans took responsibility for their own governance as evidenced by the Mayflower Compact of $1620 .^{3}$ Throughout its history, the success of the United States has generally been based on self-reliance, selfdetermination, and freedom. When the British tried to exert too much control over the American colonies and the American people, Americans revolted. After winning their independence from Britain in the late $18^{\text {th }}$ century, Americans established a self-governing democratic constitutional republic. The United States has been remarkably stable for centuries. It has operated under the same U.S. Constitution with few amendments since 1789. Americans have elected their President every four years since 1789, even during the American Civil War in which 620,000 American soldiers died.

\section{Economic Factors}

After World War II, most developed countries, except the U.S., were rebuilding their economies and societies after fighting a war on their soil. With little foreign competition, the U.S. economy boomed. The giant post-war American baby-boomer generation grew up in unprecedented peace and prosperity. From about 1947 until around 1968, the wages of the average American worker increased at a much faster rate than pay at the top our organizations. Beginning in the late 1960s and throughout the 1970s this slowly began to change. In the 1980s and picking up speed in the 1990s and 2000s, the gap between what those at the top were paid and everyone else widened dramatically. By 2005, income disparities in the U.S. were the same as in 1928, right before the onset of the Great Depression. The Financial Crisis of 2008 revealed that the American financial system and economy had become dangerously overleveraged. In an attempt to prevent massive deflation, the U.S. Federal Reserve and the U.S. government went into spending overdrive. They spent, lent, or guaranteed trillions and trillions of dollars with borrowed money. The U.S. federal debt skyrocketed. In 2000, the federal debt was just under $\$ 6$ trillion, but by early 2013, it reached $\$ 16.5$ trillion. The U.S. federal debt is now larger than the Gross Domestic Product (GDP) of the entire U.S. economy.

\section{Social, Political and Security Factors}

Tensions are rising between people in the U.S. Murder-suicides in families are becoming almost commonplace. There have been numerous random mass shootings at universities, in a crowded public theater in

\footnotetext{
${ }^{3}$ The Avalon Project, Mayflower Compact: 1620, Yale Law School Lillian Goldman Law Library, http://avalon.law.yale.edu/17th_century/mayflower.asp
} 
Colorado, at a Sikh temple in Wisconsin, and at a public school in Connecticut. The 2001 attacks on the World Trade Center and the Pentagon were the first attacks on U.S. soil since the Pearl Harbor attack in 1941 that brought the U.S. into World War II. Three thousand people died that day. These terrorist attacks propelled the U.S. into a decade of war in Iraq and Afghanistan. Several additional terrorist acts on U.S. soil have so far been thwarted. In November 2012, four Southern California men were arrested and charged with terrorism for allegedly planning to kill Americans overseas and in the U.S. ${ }^{4}$ Important American computer networks are under threat from computer hackers overseas via the Internet. ${ }^{5}$

\section{CHINA}

\section{Background}

China is the longest-running continuous civilization in world history, dating back more than five thousand years. However, its current Communist central government has only existed since 1949. Except for a brief period in the $20^{\text {th }}$ century, China has always been a "top-down" dictatorship. Throughout its long history, Chinese emperors had absolute power over the Chinese people under the emperor's "mandate from heaven." China's current constitution was put in place only in 1982.

Chinese Communist Party rule under Chairman Mao Zedong after 1949 was marked by starvation and violence. Millions died during the famine precipitated by the Great Leap Forward. Mao Zedong's Cultural Revolution sparked violence against formerly wealthy and educated Chinese elites. By the 1970s, it was clear that China's "top-down" Communist controlled and run economy based on force could never lift the living standards of the majority of the Chinese population. In the late 1970s, Chinese Premier Deng Xiaoping adopted "socialism with Chinese characteristics", proclaiming that "getting rich is glorious." The third generation post-war Chinese leader, Jiang Zemin, enshrined the role of (state-controlled) capitalism in China's constitution. In 1992, foreign direct investment exploded. China became a member of the World Trade Organization in 2001. In the space of a few short decades, China went from being a country that could barely feed itself to the second largest economy in the world. No country in history has transformed itself so quickly and so completely. Today, China remains firmly under the control of non-elected leaders of the Chinese Communist Party.

\section{Economic Factors}

China's extraordinary economic growth has been based on exports. In the last four years, China's exports have been hurt by the Great Recession in the U.S. and by the ongoing Eurozone crisis and recession. China's exports to Europe fell by about 5\% in the first eight months of 2012, compared with a year earlier. ${ }^{6}$ In the current global economic slowdown, an export-dependent economy is increasingly unsustainable.

To prevent its economy from following other countries into recession, the Chinese government provided a huge stimulus package in the amount of four trillion yuan ( $\$ 586$ billion). However, it appears that a large part of the stimulus package may have been siphoned off for excessive and wasteful investments. Local government and stateowned enterprises used cheap money to invest in real property. Land prices in China skyrocketed. By the end of 2010, official audits showed that local government debt in China was already about 10.7 trillion yuan (\$1.57 trillion). Much of that debt was in non-performing loans. There are growing concerns that China's explosive internal growth may have been based on Ponzi financing for construction projects, not on appropriate economic considerations. $^{7}$ Ghost towns and empty malls have been built. According to Holly Krambeck of the World Bank, "In Chenggong, there are more than 100,000 new apartments with no occupants." 8 Dongquan Mall, the largest mall in China, is 98\% vacant. Some now believe that China may be in the midst of an unsustainable real estate bubble that will not end well.

\footnotetext{
${ }^{4}$ Salvo, Christina, Rob McMillan, Elex Michaelson and Leticia Juarez. (11/30/2012). Terrorism Plotters Arrest: More Details Revealed. ABC News. Retrieved from: http://abclocal.go.com/kabc/story?section=news/local/inland_empire\&id=8892316

${ }^{5}$ Cybersecurity: Threats Impacting the Nation. (4/24/2012). U.S. Government Accountability Office (GAO). Retrieved from: http://www.gao.gov/products/GAO-12-666T

${ }^{6}$ Now For the Soft Part. (10/6/2012). The Economist. p. 50.

${ }^{7}$ http://www.huffingtonpost.com/dee-woo/china-economy-deleveraging b 1674951.html

${ }^{8}$ Is China an Economic Miracle or One Massive Government Sponsored FRAUD? (10/6/2012). ZeroHedge.
} 


\section{Social, Political and Security Factors}

As in the U.S., China also has a serious problem of income disparities between the "haves" and the "havenots." Its Gini coefficient, a measure of income distribution, has risen from 0.3 a quarter century ago to nearly 0.5 today, a level commonly cited as socially destabilizing. ${ }^{9}$ Resentments between people have been building. In response, China's government is attempting a nationwide crackdown on conspicuous consumption, saying that "[h] edonism, lavishness and the worship of foreign things" will not be tolerated, nor will promoting "aristocratic lifestyles". Beijing officials have banned such themes in outdoor ads. ${ }^{10}$

China has another serious problem - its population is rapidly aging. The latest government census showed that in 2009 there were 178 million Chinese over the age of 60 . The United Nations forecasts that 437 million people (one-third of the Chinese population) will be older than 60 by 2050. ${ }^{11}$ This is especially worrisome because the traditional Chinese value of caring for aging parents no longer holds true. Family bonds have been loosened by China's massive migration from the farms to the cities and its one-child policy. A fear is that China may grow old before it gets rich.

There are signs that ordinary Chinese citizens are becoming restive and more politically active. After the Tiannamen Square massacre in 1989, most Chinese were focused only on improving their economic conditions. They took little interest in political matters and rarely would ordinary citizens show support for those under attack by the Chinese government. This attitude appears to be changing. Recently, there has been increased public support in the case of an outspoken critic of the government accused of evading \$2.4 million in taxes and for a blind activist for the rights of the disabled who was sent to prison for four years. ${ }^{12}$ China's new non-elected leader, Xi Jinping, has recently taken over the top job of the Chinese Communist Party for the next decade. He will face many serious challenges in the years ahead as will the elected leaders in the United States.

\section{CORRUPTION}

The past decade has been marked by serious scandals in both the U.S. and China. The stock market crashes in the U.S. in 2000-2002 and again after the Financial Crisis of 2008 exposed rampant corruption and fraud in many essential American self-governing institutions and associations. ${ }^{13}$ These scandals were not restricted to businesses and Wall Street firms. Federal, state and local government officials, accountants, attorneys and judges, unions, educational and religious institutions, charities and nonprofits, the media, unions and others were caught in scandal as well.

Corrupt Chinese officials have been fleeing overseas with ill-gotten gains from state-owned enterprises that still make up about half of all of the non-agricultural enterprises in China. One Chinese prosecutor estimated that 18,487 officials and state-owned company executives have been caught over the past 12 years trying to leave the country with money obtained illegally. ${ }^{14}$ Typical of the problem is one Chinese official of a high-speed rail program marred by cost overruns who bought an $\$ 840,000$ home in Los Angeles while earning only $\$ 365$ a month. ${ }^{15}$ In recent decades, it has been estimated that $\$ 126$ billion may have been spirited out of the country in this way. ${ }^{16}$

\footnotetext{
${ }^{9}$ China's Growing Income Gap. (1/27/2012). Bloomberg BusinessWeek.

${ }^{10}$ China's Ad Business Faces a Crackdown. (4/11/2011). Bloomberg BusinessWeek. pp. 11-12.

${ }^{11}$ China's Demographic Tsunami. (1/5/12). Bloomberg BusinessWeek.

${ }^{12}$ Beware Low-Flying Aeroplanes: Social Tensions in China. (11/10/2011). The Economist. Retrieved from:

http://www.economist.com/blogs/analects/2011/11/social-tensions-china

${ }^{13}$ Fletcher, Pascal. (12/8/2009). Corruption Threatens Soul and Fabric of U.S. Reuters. Retrieved from: http://www.reuters.com/article/idUSTRE5B74AAI20091208

${ }_{11}^{14}$ Barbara Demock and David Pierson. (6/6/2012). China's Exodus of the Corrupt. Los Angeles Times. p. A5.

${ }^{15}$ Ibid.

${ }^{16}$ Ibid.
} 


\section{RULE OF LAW VS. RULE BY LAW}

\section{Rule of Law - The United States}

Since the U.S. follows a self-governance model, Rule of Law has been an essential component of American success over the centuries. American Rule of Law has its origins in British Rule of Law, which is almost a thousand years old. Early American settlers covenanted with God to follow whatever laws were necessary for the common good of the people under the Mayflower Compact of 1620. Laws were passed only with the consent of the people. For the first time in history, the U.S. Declaration of Independence stated American rights to "life, liberty and the pursuit of happiness" came directly from God, not through any ruler, monarch or other intermediary. The U.S. Constitution, as written and applied, is unique in the world. Power is diffused and shared among the three branches of the federal government and between the federal government and the states (and people). There are checks and balances over the power of the three arms of the federal government - the executive (the office of the U.S. President), the legislative (U.S. Congress) and the judicial branch (the U.S. Supreme Court and federal courts). Each has some power over the actions of the other branches of government. Since 1791, the individual rights of Americans have been protected by the first 10 amendments of the U.S. Constitution - the American Bill of Rights. Rule of Law requires an independent judiciary that bases its decisions solely on predictable, established ethical and legal principles, free from government influence and control. Historically, law in the U.S. has met both requirements.

\section{Rule by Law - China}

For thousands of years, Chinese rulers have held absolute power over the people. Chinese emperors ruled by force, not with the consent of the people. Self-governance based on predictable, established ethical and legal principles, followed by an independent judiciary, is a foreign concept in China. For most of China's long history, the enforcement power of its absolute rulers has been the Chinese military. Even in the current regime, the People's Liberation Army (PLA) enjoys the same rank as China's State Council, or cabinet, and the executive branch of the government can issue no orders to the PLA. ${ }^{17}$

As China transforms from a centrally planned to a more market-oriented economy, it must rely more on law rather than force. Its legal infrastructure must be trusted by investors both inside and outside of the country. Although China has made remarkable strides toward creating a fledgling legal system, the Chinese approach to law is more Rule by Law than the Rule of Law model of the United States. Rule by Law is where the law is used by the government to enforce its own political purposes. The judiciary is not independent of government influence. Decisions rendered by Chinese judges are often dictated by the results desired by the central Chinese Communist party.

For example, Section 35 of the Chinese constitution grants Chinese rights that would be familiar to an American; however, they are applied very differently. Unlike American rights granted under the Bill of Rights of the U.S. Constitution, Section 35 "rights" do not protect individual Chinese citizens from an abusive central government. Instead, Chinese courts interpret these "rights" as being subordinate to the "national interests" of the country. Chinese judges look to the directives of the Chinese central Communist government to determine what China's "national interests" are, especially in sensitive cases. ${ }^{18}$ The Chinese judiciary acts more as an enforcement arm for the central Communist government rather than an independent arbiter of right and wrong based on established and predictable ethical and legal principles and concepts of justice applying fairly and equally to all.

\footnotetext{
${ }^{17}$ Vertical Meets Horizontal. (12/1/2012). The Economist. p. 50.

${ }^{18}$ China's Constitutional Framework, Congressional-Executive Commission on China, http://www.cecc.gov/pages/virtualAcad/gov/stateconst.php; Retrieved from: Li Rui, Hu Jiwei, and others, "The Press Must Be Free!" China Rights Forum, Retrieved from: http://www.hrichina.org/content/4963; Justice System in China: Facts and Details, Retrieved from: http://factsanddetails.com/china.php?itemid=299\&catid=8; Mary Kay Magistad, Tipping the Scales: New Chinese Directive Requires Lawyers to Pledge Loyalty to the Communist Party, PRI's The World, Mar. 21, 2012, Retrieved from: http://www.theworld.org/2012/03/tipping-the-scales-new-chinese-directive-requires-lawyers-to-pledge-loyalty-to-the-communist-party/; Joseph Kahn, Deep Flaws, and Little Justice, in China's Court System, Sept. 21, 2005, Retrieved from: http://www.nytimes.com/2005/09/21/international/asia/21 confess.html?pagewanted=all
} 
Rule by Law means the ability to hold people prisoner without telling them what they are being charged with, conducting trials in secret, and not giving defendants adequate time or information to prepare an effective defense against the charges. ${ }^{19}$ Communist party members who fall out of favor can find themselves in a Soviet styled detention called "shuanggui" that involves physical torture and sleep-deprived interrogations to obtain confessions. ${ }^{20}$ Shuanggui is rooted in Party regulations instead of formal legislation and lacks the transparency afforded by a legal system. ${ }^{21}$

\section{DANGERS AHEAD}

In today's low interest rate environment, the annual interest payments on the United States' gargantuan national debt are approximately $\$ 400$ billion a year. At the current rate of federal spending, the U.S. national debt will soon be $\$ 20$ trillion. If interest rates return to their historical levels, interest payments on our national debt could top $\$ 1$ trillion a year. This would crowd out essential federal funding, including national defense. Approximately 23 million Americans are unemployed or underemployed. Unemployment has remained around 8\% for four years. Food stamp usage is at an all-time high of 47 million people. Disability claims under the Social Security system have skyrocketed. Concerns are growing that the federal government has opened up the floodgate of spending at taxpayers' expense without proper supervision or monitoring. ${ }^{22}$ The net worth of American households in 2012 is at a 43 year low. ${ }^{23}$ The U.S. federal, state and local governments have made pension and medical benefit promises to retired government workers that cannot be paid. The same is true for promises made to senior citizens under social security, Medicare and Medicaid programs. Current and future government promises are underfunded by tens of trillions of dollars.

Protests are growing in China over such things as illegal land grabs, territorial disputes with Japan and other neighboring countries, worker protests, and pollution. Tibetans have been setting themselves on fire and have stepped up their demonstrations to protest continued Chinese occupation. At least 121 people were killed in riots as the Muslim minority group, the Uighurs, continued their protests against China as well. Wealthy Chinese, worried about political turmoil caused by a serious economic slowdown, are increasingly seeking foreign citizenship in countries like the United States, Australia and Canada. ${ }^{24}$

\section{CONCLUSION}

The bottom line is that both the United States and China have serious economic, social, political and security issues on the horizon. To solve the problems both countries now have will require serious sacrifices and pain for a large portion of the population in both countries. Which form of government - one that is free or one that is not free - will best be able to adapt quickly to the constantly changing environment of the tumultuous years ahead? Will a serious economic slowdown topple the existing Communist dictatorship in China? Will gridlock and distrust in the U.S. prevent Americans from adapting fast enough to make the necessary changes to save its financial system and economy from certain catastrophe caused by corruption, fraud and over-spending? We will see.

\section{AUTHOR INFORMATION}

Dr. Linnea B. McCord is an Associate Professor of Business Law at the Graziadio School of Business and Management of Pepperdine University. Dr. McCord received a BA from the University of Sydney (including one year of law school at the University of Sydney Law School), a Juris Doctor degree from the University of Houston Law Center, and MBA from the University of Texas at Austin. E-mail: linnea.mccord@pepperdine.edu

\footnotetext{
${ }^{19}$ Retrieved from: http://www.standard.co.uk/business/rio-tinto-four-tried-behind-closed-doors-for-business-secrets-theft6795140.html; see also, Chen Guangcheng. (5/30/2012). How China Flouts its Laws. New York Times. p. A21.

$\frac{}{20}$ Jacobs, Andrew. (6/15/2012). For China's Elite, Harsh Discipline for the Accused. New York Times. p. A1.

${ }^{21}$ Official Fear: Inside a Shuanggui Investigation Facility. (7/5/2011). Human Rights Journal.

${ }^{22}$ White, Ed. (3/9/2012). Lottery Winner. Food Stamps. In Michigan, Again. The Christian Science Monitor. Retrieved from: http://www.csmonitor.com/Business/Latest-News-Wires/2012/0309/Lottery-winner.-Food-stamps.-In-Michigan.-Again

${ }^{23}$ Retrieved from: http://www.zerohedge.com/news/2012-12-02/guest-post-reality-has-consequences

${ }^{24}$ Chow, James and Angis Loten. More Wealthy Chinese Said to Prepare Exits. Wall Street Journal. p. A14.
} 
Dr. Terry Young is Professor of Economics at the Graziadio School of Business and Management at Pepperdine University. She has a BA from the University of Santo Thomas in the Philippines, a MA from the University of Colorado at Boulder, and a MA and PhD from the University of Southern California. Dr. Young has more than 30 years of teaching experience. She has been a full time faculty member at the Graziadio School since 1984. E-mail: terry.young@pepperdine.edu

Dr. Peggy J. Crawford is Professor of Finance at the Graziadio School of Business and Management at Pepperdine University. She received her BA from the University of Texas at Arlington and PhD from Purdue University. She has published over thirty articles in a variety of practitioner and academic journals. Her research focuses mainly on corporate finance, capital markets, and real estate/mortgages topics including lease vs. buy decision, return on closed-end investment funds, risk profile of adjustable-rate mortgages, impact of the budget and trade deficits, Chinese currency policy, and speculation in oil markets. E-mail: pcrawfor@pepperdine.edu (Corresponding author) 
NOTES 